\title{
МОРФОГЕНЕЗ ЛІМФОЇДНОӦ ТКАНИНИ ЩИТОПОДІБНОЇ ЗАЛОЗИ У РАННЬОМУ ВІЦІ ЗА УМОВ ЕКСПЕРИМЕНТАЛЬНОГО ПРЕНАТАЛЬНОГО АНТИГЕННОГО НАВАНТАЖЕННЯ
}

\author{
๑О. В. Федосєєва ${ }^{1}$, Ю. Б. Чайковський ${ }^{2}$ \\ 1 Запорізький державний медичний університет \\ ${ }^{2}$ Начіональний медичний університет імені О. О. Богомольчя
}

РЕЗЮМЕ. У сучасній світовій літературі велика увага приділяється питанням загального впливу інфекційного навантаження на імунну систему організму, і, як наслідок, розвитку автоімунних станів щитоподібної залози. Т-лімфоцити $є$ основними ефекторами адаптивної імунної системи і мають вирішальне значення для захисту організму від патогенних інфекційних збудників. Особливу увагу в цьому питанні привертає до себе вплив різноманітних чинників на організм вагітної, тобто пренатальна неспецифічна дія зовнішніх інфекційних антигенів на організм, які 6 мали віддалені прояви після народження.

Мета - експериментально встановити особливості морфогенезу лімфоїдної тканини щитоподібної залози у ранньому постнатальному періоді онтогенезу за умов пренатальної дії стафілококового анатоксину.

Матеріал і методи. Експериментально досліджено щитоподібні залози щурів лінії Вістар у віці від 1 до 14 доби постнатального розвитку (всього 90 тварин). Кожному плоду на 18 добу датованої вагітності під час лапаротомії, шляхом крізьматкової, крізьоболонкової підшкірної ін'єкції вводили стафілококовий анатоксин рідкий очищений адсорбований (10-14 одиниць зв'язування у 1 мл, розведений у 10 разів) в дозі 0,05 мл, тваринам контрольної групи аналогічно вводили 0,9 \% розчин $\mathrm{NaCl}$. Комплекс щитоподібної залози з ділянкою трахеї фіксували в 10 \% розчині нейтрального забуференого формаліну протягом доби. Гістологічні зрізи товщиною 3-5 мкм забарвлювали гематоксиліном і еозином, імуногістохімічно із застосуванням моноклональних антитіл CD 3 (5B2), CD4 (5B4), CD8 (32-M4), CD20 (D-10) фірми Santa Cruz Biotechnology, Inc. із дофарбовуванням ядер гематоксиліном Майера. Фотодокументацію досліджуваних об'єктів виконано з використанням мікроскопа Carl Zeiss «Primo Star» з використанням камери AхіоCam, комплекс морфометричних досліджень виконувався за допомогою програми Zeiss Zen (2017). Статистичний аналіз отриманих результатів проводили за допомогою персонального комп'ютера на базі операційної системи Windows XP за допомогою статистичного пакета «Statistica for Windows 6.0" (StatSoftInc.), програма Excel (Microsoft Office, USA).

Результати. Внутрішньоплідне введення стафілококового анатоксину призвело до часткової лімфоцитарної інфільтрації строми щитоподібної залози і формування внутрішньоорганної дифузної лімфоїдної тканини здебільшого з CD 3+ та CD 4+ лімфоцитів (збільшення кількості Т-лімфоцитів за цей період у 75,1 раза), та кооперації їі у вигляді лімфоїдного вузлика на 14 добу постнатального життя, клітинний склад якого був імуногістохімічно представлений CD 3+CD 4+ та CD 3+CD 8+ Т-лімфоцитами, що супроводжувалося розширенням і явищами стазу у венулах, активацією мастоцитів і макрофагів. Така морфологічна картина у щитоподібних залозах антигенпремійованих тварин наявна на периферії залози. Таким чином, інтенсивні зміни в імунологічному компартменті щитоподібної залози з формуванням дифузної лімфоїдної тканини у щурів раннього віку після пренатальної дії стафілококового анатоксину обумовлені генералізованим пренатальним антигенним навантаженням організму в цілому та є проявами реактивності у процесі формування антигеннезалежного диференціювання Т-лімфоцитів у тимусі.

КлючОВІ СлОВА: щитоподібна залоза; стафілококовий анатоксин; щури; імунологічна реактивність.

Вступ. У сучасних дослідженнях велике значення надають вивченню механізмів розвитку лімфоїдної тканини щитоподібної залози (ЩЗ) за умов реакції імунної системи організму на різноманітні інфекції [1-3]. Більшість патологічних процесів $\epsilon$ наслідком вичерпання резервів адаптації як організму в цілому, так і його органів. У результаті виникають нові форми взаємовідносин, які $\epsilon$ необхідними і гармонійними у певних аспектах, але конфліктують із можливостями і потребами в інших компартментах системи, що проявляється у вигляді морфологічних та клінічних ознак тієї чи іншої хвороби, включаючи автоімунні стани щ3 [4-6].

У розвитку патологічних станів ЩЗ ключову роль відіграють збудники інфекцій. Розглядається загальний вплив інфекційного навантаження на імунну систему організму, i, як наслідок, розви- ток автоімунних станів щ3. Інфекційні агенти (бактеріальні, вірусні, грибкові, спірохети тощо) можуть ініціювати автоімунні реакції в ЩЗ за допомогою різноманітних механізмів, таких як індукування модифікацій власних антигенів, імітація автомолекул, зміна ідіотипової мережі, формування імунних комплексів та індукція експресії молекул гістосумісності на тироцитах $[7,8]$. До пошкодження тканин при автоімунних захворюваннях ЩЗ призводить як клітинно-опосередкована, так і гуморальна реакція імунної системи. Т-лімфоцити $\epsilon$ основними ефекторами адаптивної імунної системи і мають вирішальне значення для захисту організму від патогенних інфекційних збудників. Аберантні Т-лімфоцити відіграють вирішальну роль у патогенезі автоімунних станів, не тільки допомагаючи В-клітинам у продукції авто- 
Огляди літератури, оригінальні дослідження, погляд на проблему, випадок з практики, короткі повідомлення антитіл, а й проникаючи в тканини органа, що призводить до його імунопатології $[8,9]$.

Особливу увагу в цьому питанні привертає вплив різноманітних чинників на організм вагітної, тобто пренатальна неспецифічна дія зовнішніх інфекційних антигенів на організм, які 6 мали віддалені прояви після народження $[10,11]$. Антигенне навантаження у критичні терміни онтогенезу може викликати значні «поломки» в імунній системі дитини [12]. Наслідком перенесених інфекцій може бути ініціація морфологічних змін органів та забар'єрних структур, тобто ці інфекції можуть не призводити до стійких змін структури, а тільки залишати постійний імунологічний «фон» в органі та організмі в цілому, який при впливі різних чинників може в подальшому ініціювати патологічні стани, включаючи автоімунні захворювання і т. д. [10, 12]. Цей ефект досягається різними шляхами: імунологічно, модифікацією подальшого імунологічно залежного розвитку структур, або морфологічно, шляхом прямого пошкодження, викликаного інфекцією. Особливості взаємодії плода або новонародженого з екзогенними антигенами можуть бути вирішальними у формуванні їх імунного статусу в майбутньому [9-12].

Т-лімфоцити походять із стовбурових клітинпопередниць червоного кісткового мозку і печінки плода та диференціюються у зрілі типи клітин після міграції до тимуса. При впливі пренатального антигенного навантаження відбувається передчасний вихід Т-лімфоцитів з тимуса, які в тканинах змінюють не тільки терміни розвитку структурних елементів, а й їх імунологічну толерантність тощо $[12,13]$. Імунологічна автотолерантність індукується протягом перинатального періоду, коли незрілі лімфоцити в тимусі зазнають дії власних антигенів. У цей вирішальний момент клональна делеція або індукована анергія автореактивних Т-клітин визначає автотолерантність до автоантигенів. Однак ці механізми не єдині, і деякі автореактивні клітини можуть існувати в організмі в нормі.

Низкою досліджень доведено, що серед факторів зовнішнього середовища у розвитку патологічних станів Щ3 ключову роль відіграють збудники інфекцій. У багатьох випадках саме «тягар інфекцій» з дитинства, а не одна інфекція, відповідальна за індукцію автоімунітету [12-14].

Ланка досліджень присвячена вивченню морфологічних змін лімфоїдного компонента різних органів за умов пренатальної дії антигенів [15-17], але детального вивчення морфогенезу лімфоїдної тканини щитоподібної залози за умов експериментального пренатального антигенного навантаження не проводилось.

Мета - експериментально встановити особливості морфогенезу лімфоїдної тканини щито-

подібної залози у ранньому постнатальному періоді онтогенезу за умов пренатальної дії стафілококового анатоксину.

Матеріал і методи дослідження. Матеріалом дослідження була щЗ щурів лінії Вістар у віці від 1 до 14 доби постнатального розвитку (90 тварин), по 6 тварин у кожній групі. Досліджено три групи тварин на 1, 3, 7, 11, 14 добу постнатального періоду життя: І гр. - інтактні тварини (норма); II гр. - контрольна, тваринам якої вводили 0,9% розчин $\mathrm{NaCl}$ на 18 добу датованої вагітності; III експериментальні тварини, яким вводили стафілококовий анатоксин рідкий очищений адсорбований (10-14 одиниць зв'язування у 1 мл, розведений у 10 разів) на 18 добу датованої вагітності за методом Волошина М. А. (пат. 49377, Україна, 2010 та пат. 63020, Україна, 2011). Введення плодам антигену та 0,9 \% розчину $\mathrm{NaCl}$ здійснювалось під час лапаротомії шляхом крізьматкової, крізьоболонкової підшкірної ін'єкції у міжлопаткову ділянку в дозі 0,05 мл кожному плоду.

Утримання та догляд за тваринами і всі маніпуляції проводили відповідно до положень «Європейської конвенції про захист хребетних тварин, які використовуються для експериментальних та інших наукових цілей» (Страсбург, 1985), Гельсінської декларації Генеральної асамблеї Всесвітньої медичної асоціації (2000), «Загальних етичних принципів експериментів на тваринах», ухвалених Першим національним конгресом з біоетики (Київ, 2001), Закону України «Про захист тварин від жорстокого поводження» (від 21.02.2006 № 3447-IV, редакція від 09.12.2015, підстава 766-19).

Комплекс щитоподібної залози з ділянкою трахеї фіксували в 10 \% розчині нейтрального забуференого формаліну протягом доби. Об'єкти заливали у парафінові блоки загальноприйнятим методом. Гістологічні зрізи товщиною 3-5 мкм забарвлювали гематоксиліном і еозином для оглядової світлової мікроскопії та проведення морфометрії. Кількість лімфоцитів та макрофагів підраховували у гістологічних зрізах у стандартизованому полі зору мікроскопу при збільшенні об'єктива ×40 (кількість клітин на 40000 мкм²) 3 подальшим обчисленням щільності розташуван-

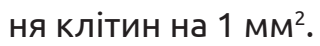

Імуногістохімічне дослідження виконано відповідно до протоколу, рекомендованого до конкретного антитіла фірми-виробника, та проведено з метою ідентифікації груп лімфоцитів у лімфоїдній тканині. Використовували моноклональні антитіла CD 3 (5B2), CD4 (5B4), CD8 (32-M4), CD20 (D-10) фірми Santa Cruz Biotechnology, Inc. із застосуванням методу непрямого забарвлення імунопероксидазою за допомогою кон'югованих HRP мишачих IgG-зв'язуючих білків, m-IgGк BP-HRP, з по- 
Огляди літератури, оригінальні дослідження, погляд на проблему, випадок з практики, короткі повідомлення дальшою інкубацією в субстраті пероксидази та суміші хромогену DAB-3-діамінобензидину тетрахлориду та дофарбовуванням ядер гематоксиліном Майера, дегідратацією, просвітленням та поміщенням у бальзам.

Результат розцінювали як позитивний при випаданні солей хромогену у вигляді специфічної реакції (ядерна, цитоплазматична реакція залежно від локалізації антигену). Інтенсивність відкладання бензидинової мітки оцінювали методом фотоцифрової морфометрії із використанням програми Image J у кожному випадку в 5 стандартизованих полях зору мікроскопа зі збільшенням 400 (об'єктив ×40, окуляр ×10), де визначали інтенсивність експресії маркера і кількісно градуювали її в умовних одиницях оптичної щільності: негативна реакція - 0-20; низький рівень експресії- 21-50; помірний рівень експресії - 51-100; високий рівень експресії - більше 100.

3 метою контролю методу була проведена серія досліджень з використанням позитивних і негативних зразків, які служили еталонами.

Фотодокументування досліджуваних об'єктів виконано з використанням мікроскопа Carl Zeiss "Primo Star» з використанням камери AxioCam, комплекс морфометричних досліджень виконували за допомогою програми Zeiss Zen (2017).

Статистичний аналіз отриманих результатів проводили за допомогою персонального комп'ютера на базі операційної системи Windows XP за допомогою статистичного пакету «Statistica for Windows 6.0» (StatSoftlnc.), програма Excel (Microsoft Office, USA). Усі результати досліджень фіксувалися в журналах та протоколах первинної документації, а також з використанням електронних носіїв інформації. Гіпотезу про нормальність розподілу досліджуваних показників перевіряли 3 використанням критерію Шапіро - Уїлка. Обчислювали медіану, нижній та верхній квартилі, дані представляли у вигляді Me (Q1; Q3). Достовірність відмінностей між середніми оцінювали за допомогою параметричного t-критерію Стьюдента при нормальному розподілі і непараметричного U-критерію Манна - Уітні - при ненормальному розподілі та вважали статистично значущою при рівні достовірності не менше 95 \%. Для всіх видів аналізу відмінності вважали достовірними при $p<0,05$.

Результати й обговорення. У новонароджених тварин експериментальної групи 1-ї доби життя у прошарках міжфолікулярної сполучної тканини ЩЗ виявляються макрофаги та $\mathrm{CD} \mathrm{3} 3^{+} \mathrm{CD} 4^{+}$лімфоцити, медіана кількості цих клітин становить $1,43(1,11 ; 1,56)$ та $1,26(0,8 ; 1,52)$ відповідно, на відміну від таких у контрольній - $1,31(0,85 ; 1,47)$ і $0,12(0 ; 0,18)$ та інтактній групах $1,28(0,91 ; 1,45)$ i $0,14(0,1 ; 0,16)$. На серійних зрізах щз поодинокі CD $3^{+}$лімфоцити та макрофаги здебільшого виявлялися лише у капсулярній сполучній тканині. Такі зміни, наявні з народження у щурів експериментальної групи, $\epsilon$ доказом генералізованої реакції з боку імунної системи на пренатально введений антиген, яка запускає зміни у місцевому імунологічному стані Щ3, що пов'язано зі змінами диференціювання Т-лімфоцитів, описаних і в інших органах ланкою вчених $[15,16]$. На 3-ю добу життя на тлі розширених та повнокровних венул периферійної зони щитоподібної залози у експериментальних тварин візуалізується діапедез (рис. 1, а) лімфоцитів з кровоносного русла у міжфолікулярну сполучну тканину. Популяція Т-лімфоцитів представлена здебільшого Т-хелперами CD $4^{+}$лімфоцитами, але трапляються і поодинокі CD 8+ цитотоксичні Т-лімфоцити. При цьому кількість макрофагів та мастоцитів зростає, як у порівнянні з контролем, так і з попереднім строком.

Починаючи з 7-ї доби життя у тварин експериментальної групи на тлі пренатального антигенного навантаження стафілококовим анатоксином у підкапсулярній зоні щитоподібної залози збільшуються кількість та площа розподілу малих і середніх лімфоцитів, візуалізується поширення їх навколо фолікулів. Найчастіше такі дифузні скупчення лімфоцитів локалізуються поблизу межування часток щитоподібної залози із паращитоподібними залозами, але трапляються й у товщі периферійної зони часток (рис. 1, 6). У центральних частинах часток щитоподібних залоз таких змін не виявлено, як і у тварин контрольної та інтактної груп. У тварин експериментальної групи з 7-ї по 14-у добу постнатального періоду життя спостерігалися збільшення кількості CD $3^{+}$лімфоцитів та макрофагів, і ці підвищення були не тільки порівняно з контрольною та інтактною групами (у 75,1 та 9,3 раза відповідно на умовну одиницю площі), а й залежали від віку тварин (у 4,2 та 1,4 раза відповідно на умовну одиницю площі). У цей період уперше імуногістохімічно виявляються клітини 3 CD 20 позитивною експресією, які відповідно належать до В-лімфоцитарного пулу з медіаною кількості $1,28(0,95 ; 1,36)$ на умовну одиницю площі. Навколо венул у місцях формування дифузної лімфоїдної тканини виявляються мастоцити з метахроматичними гранулами без ознак масової дегрануляції. Починаючи з 11-ї доби у дифузній лімфоїдній тканині щитоподібної залози щурів після пренатального антигенного навантаження імуногістохімічно ідентифікуються CD $8+$ лімфоцити в кількості $13,81(10,64 ; 15,56)$ на умовну одиницю площі, достовірно збільшується кількість CD 20+-лімфоцитів у 1,44 раза, порівняно з попереднім експериментальним строком. Такі різкі хвилеподібні підйоми у 
Огляди літератури, оригінальні дослідження, погляд на проблему, випадок з практики, короткі повідомлення кількісному складі імунокомпетентних клітин насамперед пов'язані з тригерною появою та збільшенням кількості CD 8+ та CD 20+-лімфоцитів, що запускає механізм утворення лімфоїдного скуп-

чення та імунологічних взаємодій як з клітинними елементами строми, так і паренхіми ЩЗ, формуючи вже структуру місцевого імунологічного нагляду $[9,10,12]$.
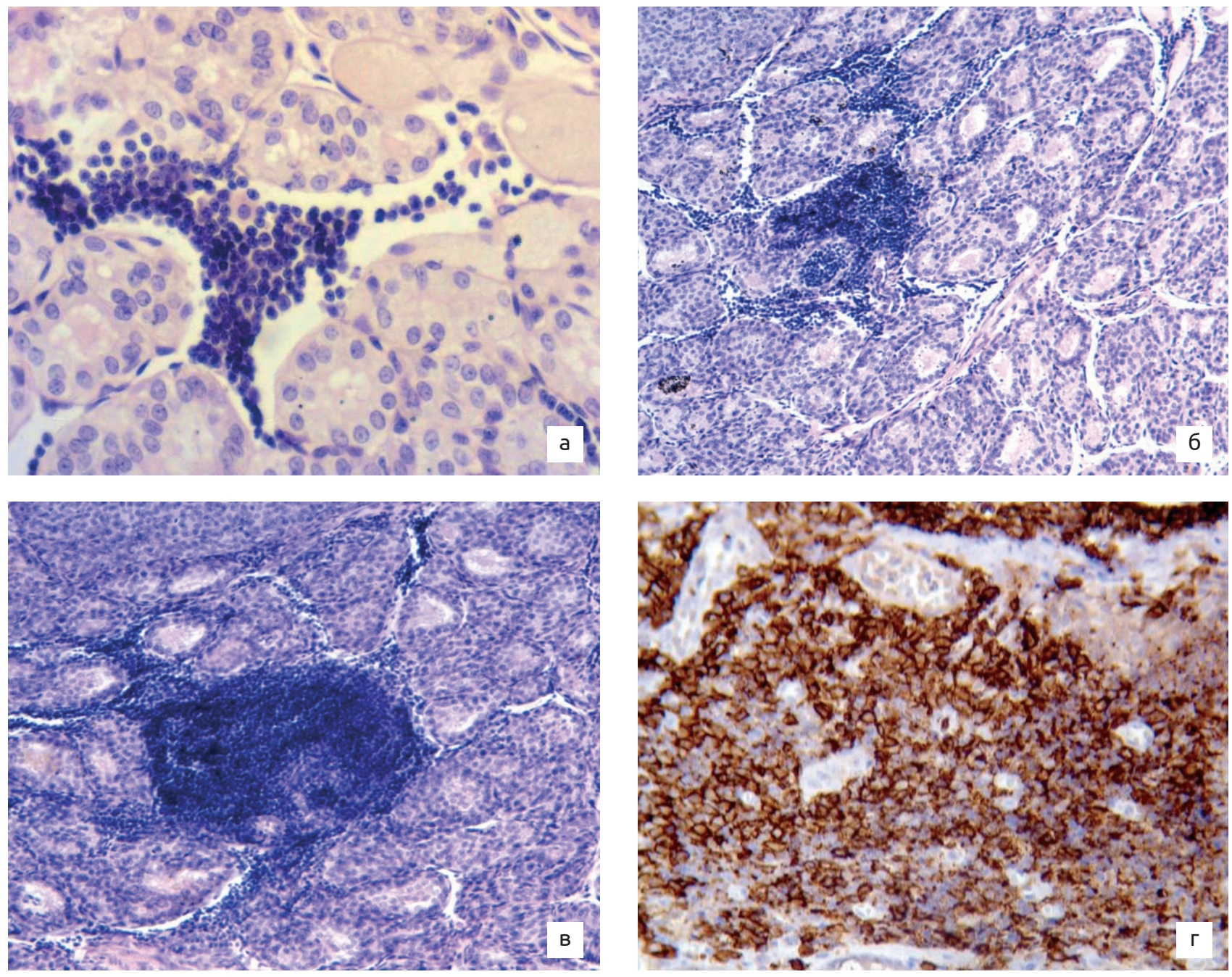

Рис. 1. Етапність формування дифузної лімфоїдної тканини щитоподібної залози тварин експериментальної групи після пренатального антигенного навантаження стафілококовим анатоксином: а - 3 доба життя, збільшення $\times 400$; 6 - 7 доба життя, збільшення ×200; в - 14 доба життя, збільшення ×200. Забарвлення: гематоксилін та еозин. г- розподіл Т-лімфоцитів CD $3^{+}$у лімфоїдному вузлику, що формується, збільшення ×400, імуногістохімічна реакція з CD 3 (5B2) моноклональним антитілом при дофарбовуванні гематоксиліном Майера.

На 14-у добу у тварин експериментальної групи візуалізується лімфоїдний вузлик, який складається переважно з малих та середніх лімфоцитів, імуногістохімічно ідентифікованих як CD $3^{+} \mathrm{CD} 4^{+}$ з медіаною кількості 178,96 (175,81; 182,37), та CD $3^{+}$CD $8^{+}-18,44(14,02 ; 22,15)$, та макрофагів $13,67(7,70 ; 16,79)$, без гермінативного центру та структуризацією оточуючих колагенових волокон у вигляді капсули, з міжфолікулярними тяжами лімфоцитів (рис. 1, в, г). Водночас у тварин інтактної та контрольної груп імунокомпетентні клітини візуалізуються поодиноко у сполучнотканинних прошарках між фолікулами колоїдного типу або периваскулярно локаціями 2-4 лімфоцитів. Серед лімфоцитів імуногістохімічно виявляються CD 3+- та CD $4^{+}$-лімфоцити.

Висновки. Інтенсивні зміни в імунологічному компартменті ЩЗ з формуванням дифузної лімфоїдної тканини у щурів раннього віку після пренатальної дії стафілококового анатоксину обумовлені генералізованим пренатальним антигенним навантаженням організму в цілому та $є$ проявами реактивності у процесі формування антигенонезалежного диференціювання Т-лімфоцитів у тимусі.

Перспективи подальших досліджень. Питання змін в імунологічному статусі за умов пре- 
Огляди літератури, оригінальні дослідження, поглядн на натального антигенного навантаження потребує подальшого детального вивчення, що важливо для вирішення питань профілактичної та клінічної медицини, особливо з огляду на розвиток автоімунних станів щитоподібної залози.

\section{ЛITEPATУРA}

1. Mateu-Salat M. SARS-COV-2 as a trigger for autoimmune disease: Report of two cases of Graves' disease after COVID-19 / M. Mateu-Salat, E. Urgell, A. Chico // J. Endocrinol. Invest. - 2020. - Vol. 43 (10). - P. 1527-1528. https://doi.org/10.1007/s40618-020-01366-7.

2. Brancatella A. Subacute thyroiditis after sars-COV-2 infection / A. Brancatella // J. Clin. Endocrinol. Metab. 2020. - Vol. 105 (7). - P. 276. https://doi.org/10.1210/clinem/dgaa276.

3. Harrington W. E. Malaria in pregnancy shapes the development of foetal and infant immunity / W. E. Harrington, A. Kakuru, P. Jagannathan // Parasite Immunol. 2019. - Vol. 41 (3). - P. e12573. https://doi.org/10.1111/ pim.12573.

4. Liu P. The immunologic status of newborns born to SARS-CoV-2-infected mothers in Wuhan, China / P. Liu // J. Allergy Clin. Immunol. - 2020. - Vol. 146 (1). - P. 101109.e1. https://doi.org/10.1016/j.jaci.2020.04.038.

5. Zangiabadian M. Associations of Yersinia Enterocolitica Infection with Autoimmune Thyroid Diseases: A Systematic Review and Meta-Analysis / M. Zangiabadian // Endocrine, Metabolic \& Immune Disorders. - 2021. Vol. 21 (4). - P. 682-687. https://doi.org/10.2174/1871530 320666200621180515.

6. Шідловський В. О. Тиреоїдит Хашимото: сучасні погляди на патогенез (огляд літератури) / В. О. Шідловський // Международный эндокринологический журнал. - 2020. - Т. 16, № 4. - С. 349-354. doi: $10.22141 / 2224-0721.16 .4 .2020 .208489$.

7. Здор В. В. Новые участники нарушения толерантности к антигенам щитовидной железы: к концепции иммунопатогенеза аутоиммунных заболеваний щитовидной железы (обзор литературы) / В. В. Здор, Е. В. Маркелова, Б. И. Гельцер // Медицинская иммунология. - 2016. - Т. 18, № 3. - С. 209-220. https://doi.org/ 10.15789/1563-0625-2016-3-209-220.

8. Owen D. L. Regulatory T cell development in the thymus / D. L. Owen, L. E. Sjaastad, M. A. Farrar // J. Immunol. - 2019. - Vol. 203 (8). - P. 2031-2041. https://doi. org/10.4049/jimmunol.1900662.

9. McLachlan S. M. Breaking tolerance to thyroid antigens: changing concepts in thyroid autoimmunity / S. M. McLachlan, B. Rapoport // Endocr. Rev.- 2014. - Vol. 35 (1). P. 59-105. https://doi.org/10.1210/er.2013-1055.

\section{REFERENCES}

1. Mateu-Salat, M., Urgell, E., \& Chico, A. (2020). SARS-COV-2 as a trigger for autoimmune disease: report of two cases of Graves' disease after COVID-19. Journal of Endocrinological Investigation, 43 (10), 1527-1528. https:// doi.org/10.1007/s40618-020-01366-7

2. Brancatella, A. (2020). Subacute thyroiditis after sars-COV-2 infection. J. Clin. Endocrinol. Metab., 105 (7), dgaa276. doi.org/10.1210/clinem/dgaa276
10. Jonsdottir B. Are Perinatal Events Risk Factors for Childhood Thyroid Autoimmunity?. / B. Jonsdottir // Eur. Thyroid J. - 2017. - Vol. 6 (6). - P. 298-306. https://doi. org/10.1159/000479964.

11. Fedosieieva O. V. Morphogenesis of rat's thyroid gland in preweaning period after prenatal influence of staphylococcal toxoid / O. V. Fedosieieva // World of Medicine and Biology. - 2020. - Vol. 3 (73). - P. 230-234. https:// doi.org/10.26724/2079-8334-2020-3-73-230-234.

12. Kristensen B. Altered balance between self-reactive T helper (Th)17 cells and Th10 cells and between fulllength forkhead box protein 3 (FoxP3) and FoxP3 splice variants in Hashimoto's thyroiditis / B. Kristensen // Clin. Exp. Immunol. - 2015. - Vol. 180 (1). - P. 58-69. https://doi. org/10.1111/cei.12557.

13. Bossowski A. Decreased proportions of CD4 + IL17+/CD4 + CD25 + CD127- and CD4 + IL17+/CD4 + CD25 + CD127 - FoxP3+ T cells in children with autoimmune thyroid diseases / A. Bossowski // Autoimmunity. - 2016. Vol. 49 (5). - P. 320-328. https://doi.org/10.1080/0891693 4.2016.1183654.

14. A systematic review on thyroid organoid models: time-trend and its achievements / H. Samimi, R. Atlasi, S. Parichehreh-Dizaji [et al.] // American Journal of Physiology - Endocrinology and Metabolism. - 2021. - № 320 (3). P. 581-590. https://doi.org/10.1152/ajpendo.00479.2020.

15. Tolerance and immunity to pathogens in early life: insights from HBV infection / M. Hong, A. Bertoletti [et al.] // Semin. Immunopathol. - 2017. - Vol. 39 (6). - P. 643652. https://doi.org/10.1007/s00281-017-0641-1.

16. Особливості морфогенезу та реактивності печінки щурів після внутрішньоутробної дії антигенів / П. В. Богданов, М. С. Щербаков [та ін.] // Актуальні питання мед. науки та практики. - 2015. - Вип. 82, Т. 1, Кн. 2. - С. 151-157.

17. Чернявський А. В. Динаміка вмісту PNA+лімфоцитів в міокарді серця щурів у постнатальному періоді в нормі та після внутрішньоутробного введення антигену / Актуальні проблеми морфології в теоретичній та практичній медицині : матеріали наук.-прак. конф. з міжнар. участю, приуроченої 75-річчю з дня заснування Вищого державного навчального закладу України «Буковинський державний медичний університет». - 2019. - С. 110-111.

3. Harrington, W.E., Kakuru, A., Jagannathan, P. (2019). Malaria in pregnancy shapes the development of foetal and infant immunity. Parasite Immunology, 41 (3), e12573. https://doi.org/10.1111/pim.12573

4. Liu, P. (2020). The immunologic status of newborns born to SARS-CoV-2-infected mothers in Wuhan, China. J. Allergy Clin. Immunol., 146(1), 101-109.e1. https:// doi.org/10.1016/j.jaci.2020.04.038 
Огляди літератури, оригінальні дослідження, погляд на проблему, випадок з практики, короткі повідомлення

5. Zangiabadian, M. (2021). Associations of Yersinia Enterocolitica Infection with Autoimmune Thyroid Diseases: A Systematic Review and Meta-Analysis. Endocrine, Metabolic \& Immune Disorders, 21 (4)., P. 682-687. https://doi. org/10.2174/1871530320666200621180515

6. Shidlovskyi, V.O. (2020). Tyreoidyt Khashymoto: suchasni pohliady na patohenez (ohliad literatury). Hashimoto's thyroiditis: modern views on the pathogenesis (literature review) Mezhdunarodnyj Endokrinologicheskij Zhurnal, - International Journal of Endocrinology 16, 4, 349354. doi: 10.22141/2224-0721.16.4.2020.208489 [in Ukrainian].

7. Zdor, V.V., Markelova, E.V., \& Gel'cer, B.I. Novye uchastniki narusheniya tolerantnosti k antigenam shchitovidnoj zhelezy: k koncepcii immunopatogeneza autoimmunnyh zabolevanij shchitovidnoj zhelezy (obzor literatury). New participants in the violation of tolerance to thyroid antigens: to the concept of immunopathogenesis of autoimmune thyroid diseases (literature review) Medicinskaya Immunologiya, - Medical Immunology, 18 (3), 209-220. https://doi.org/ 10.15789/1563-0625-2016-3-209-220 [in Russian].

8. Owen, D.L., Sjaastad, L.E., Farrar, M.A. (2019). Regulatory T cell development in the thymus. J Immunol., 203(8), 2031-2041. https://doi.org/10.4049/jimmunol.1900662

9. McLachlan, S.M., \& Rapoport, B. (2014). Breaking tolerance to thyroid antigens: changing concepts in thyroid autoimmunity. Endocrine Reviews, 35 (1), 59-105. https://doi.org/10.1210/er.2013-1055

10. Jonsdottir, B., Lundgren, M., Wallengren, S., Lernmark, Å., Jönsson, I., Elding Larsson, H., \& DiPiS Study Group (2017). Are Perinatal Events Risk Factors for Childhood Thyroid Autoimmunity?. European Thyroid Journal, 6 (6), 298-306. https://doi.org/10.1159/000479964

11. Fedosieieva, O.V. (2020) Morphogenesis of rat's thyroid gland in preweaning period after prenatal influence of staphylococcal toxoid. World of Medicine and Biology, 3 (73), 230-234. https://doi.org/10.26724/2079-83342020-3-73-230-234

12. Kristensen, B., Hegedüs, L., Madsen, H.O., Smith, T.J., \& Nielsen, C. H. (2015). Altered balance between self-reactive Thelper (Th) 17 cells and Th10 cells and between fulllength forkhead box protein 3 (FoxP3) and FoxP3 splice variants in Hashimoto's thyroiditis. Clinical and Experimental Immunology, 180 (1), 58-69. https://doi.org/10.1111/ cei. 12557

13. Bossowski, A., Grubczak, K., Singh, P., Radzikowska, U., Dabrowska, M., Sawicka, B., Bossowska A., \& Moniuszko, M. (2015). Analysis of B regulatory cells with phenotype CD19+, CD24hi, CD27+, IL-10+ and CD19+, IL-10+ in the peripheral blood of children with Graves' disease and Hashimoto's thyroiditis. Pediatr. Endocrinol. 14 (1), 40. https://doi.org/10.18544/EP-02.14.01.1552

14. Samimi, H., Atlasi, R., Parichehreh-Dizaji, S., Khazaei, S., Akhavan Rahnama, M., Seifirad, S., \& Haghpanah, V. (2021). A systematic review on thyroid organoid models: time-trend and its achievements. American Journal of Physiology - Endocrinology and Metabolism, 320 (35), 81590. doi: 10.1152/ajpendo.00479.2020

15. Hong, M., \& Bertoletti, A. (2017). Tolerance and immunity to pathogens in early life: insights from HBV infection. Seminars in Immunopathology, 39 (6), 643-652. https://doi.org/10.1007/s00281-017-0641-1

16. Shcherbakov, M.S., \& Bohdanov, P.V. (2015). Osoblyvosti morfohenezu ta reaktyvnosti pechinky shchuriv pislia vnutrishnoutrobnoi dii antyheniv [Features of morphogenesis and reactivity of the liver of rats after intrauterine action of antigens ]. Aktualni pytannia med. nauky ta praktyky-Current Issues of Medical Science and Practice, 82 (1), 2, 151-157 [ in Ukrainian].

17. Cherniavskyi, A.V. (2019). Dynamika vmistu PNA+limfotsytiv v miokardi sertsia shchuriv u postnatalnomu periodi v normi ta pislia vnutrishnoutrobnoho vvedennia antyhenu \{The dynamics of the content of PNA + lymphocytes in the myocardium of the heart of rats in the postnatal period in normal and after intrauterine administration of antigen] Aktualni problemy morfolohii $v$ teoretychnii ta praktychnii medytsyni : materialy nauk.-prak. konf. z mizhnar. uchastiu, pryurochenoi 75-richchiu z dnia zasnuvannia Vyshchoho derzhavnoho navchalnoho zakladu Ukrainy "Bukovynskyi derzhavnyi medychnyi universytet", Actual problems of morphology in theoretical and practical medicine: materials of scientific-practical. conf. with international participation, timed to the 75th anniversary of the founding of the Higher State Educational Institution of Ukraine "Bukovynian State Medical University".110-111 [in Ukrainian].

\title{
МОРФОГЕНЕЗ ЛИМФОИДНОЙ ТКАНИ ЩИТОВИДНОЙ ЖЕЛЕЗЫ В РАННЕМ ВОЗРАСТЕ В УСЛОВИЯХ ЭКСПЕРИМЕНТАЛЬНОЙ ПРЕНАТАЛЬНОЙ АНТИГЕННОЙ НАГРУЗКИ
} ๑О. В. Федосеева ${ }^{1}$ Ю. Б. Чайковский ${ }^{2}$

\author{
1 Запорожский государственный медицинский университет \\ ${ }^{2}$ Национальный медицинский университет имени А. А. Богомольца
}

РЕЗЮМЕ В современной мировой литературе большое внимание уделяется вопросам общего воздействия инфекционной нагрузки на иммунную систему организма, и, как следствие, развитию аутоиммунных состояний щитовидной железы. Т-лимфоциты являются основными эффекторами адаптивной иммунной системы и имеют решающее значение для защиты организма от патогенных инфекционных возбудителей. Особое внимание в этом вопросе привлекает к себе влияние различных факторов на организм беременной, то есть пренатальное неспецифическое действие внешних инфекционных антигенов на организм, которые имеют отдаленные проявления после рождения.

Цель - экспериментально установить особенности морфогенеза лимфоидной ткани щитовидной железы в раннем постнатальном периоде онтогенеза в условиях пренатального действия стафилококкового анатоксина. 
Огляди літератури, оригінальні дослідження, погляд на проблему, випадок з практики, короткі повідомлення

Материал и методы. Экспериментально исследованы щитовидные железы крыс линии Вистар в возрасте от 1 до 14 суток постнатального развития (всего 90 животных). Каждому плоду на 18 сутки датированной беременности во время лапаротомии путем чрезматочной, чрезоболочной подкожной инъекции вводили стафилококковый анатоксин жидкий очищенный адсорбированный (10-14 единиц связывания в 1 мл, разведенный в 10 раз) в дозе 0,05 мл, животным контрольной группы аналогично вводили 0,9 \% раствор NaCl. Комплекс щитовидной железы с участком трахеи фиксировали в 10 \% растворе нейтрального забуференного формалина в течение суток. Гистологические срезы толщиной 3-5 мкм окрашивали гематоксилином и эозином, иммуногистохимически с применением моноклональных антител CD 3 (5B2), CD4 (5B4), CD8 (32-M4), CD20 (D-10) фирмы Santa Cruz Biotechnology, Inc. с докрашиванием ядер гематоксилином Майера. Статистический анализ полученных результатов проводили с помощью персонального компьютера на базе операционной системы Windows XP с помощью статистического пакета «Statistica for Windows 6.0" (StatSoftInc.), программа Excel (Microsoft Office, USA).

Результаты. Внутриплодное введение стафилококкового анатоксина привело к частичной лимфоцитарной инфильтрации стромы щитовидной железы и формированию внутриорганной диффузной лимфоидной ткани большей частью из CD 3+ и CD 4+ лимфоцитов (увеличение количества Т-лимфоцитов за этот период в 75,1 раза) и кооперации ее в виде лимфоидного узелка на 14 сутки постнатальной жизни, клеточный состав которого был иммуногистохимически представлен $\mathrm{CD} 3^{+} \mathrm{CD} 4^{+}$и CD $3^{+} \mathrm{CD} 8^{+}$Т-лимфоцитами. Это сопровождалось расширением и явлениями стаза в венулах, активацией тучных клеток и макрофагов. Такая морфологическая картина в щитовидной железе антигенпремированных животных наблюдалась на периферии железы. Таким образом, интенсивные изменения в иммунологическом компартменте щитовидной железы с формированием диффузной лимфоидной ткани у крыс раннего возраста после пренатального действия стафилококкового анатоксина обусловлены генерализованной внутриутробной антигенной нагрузкой организма в целом и являются проявлениями реактивности в процессе формирования антигеннезависимого дифференцирования Т-лимфоцитов в тимусе.

КЛЮЧЕВЫЕ СЛОВА: щитовидная железа; стафилококковый анатоксин; крысы; иммунологическая реактивHOCTь.

\title{
MORPHOGENESIS OF THE LYMPHOID TISSUE OF THE THYROID GLAND AT AN EARLY AGE UNDER CONDITIONS OF EXPERIMENTAL PRENATAL ANTIGENIC LOAD
}

\author{
๑O. V. Fedosieieva', Yu. B. Chaikovsky² \\ ${ }^{1}$ Zaporizhzhia State Medical University \\ ${ }^{2}$ O. Bohomolets National Medical University
}

SUMMARY. In modern world literature, much attention is paid to the general impact of the infectious load on the immune system of the body, and as a consequence, the development of autoimmune conditions of the thyroid gland. T-lymphocytes are the main effectors of the adaptive immune system and are critical for the body's defense against pathogenic infectious agents. Particular attention in this matter is attracted by the influence of various factors on the body of a pregnant woman, that is, the prenatal nonspecific effect of external infectious antigens on the body, which have distant manifestations after birth.

The aim - to establish experimentally the features of the morphogenesis of the thyroid lymphoid tissue in the early postnatal period of ontogenesis under conditions of prenatal action of staphylococcal toxoid.

Material and Methods. Thyroid glands of Wistar rats aged from 1 to 14 days of postnatal development (90 animals in total) were experimentally investigated. On the 18th day of a dated pregnancy, each fetus was injected with purified adsorbed staphylococcal toxoid liquid (10-14 binding units in $1 \mathrm{ml}$, diluted 10 times) at a dose of $0.05 \mathrm{ml}$ during laparotomy, by trans-uterine, transcoccal subcutaneous injection. $0.9 \% \mathrm{NaCl}$ solution. The complex of the thyroid gland with a portion of the trachea was fixed in a $10 \%$ solution of neutral buffered formalin for 24 hours. Histological sections 3-5 $\mu \mathrm{m}$ thick were stained with hematoxylin and eosin, immunohistochemically using monoclonal antibodies CD 3 (5B2), CD4 (5B4), CD8 (32-M4), CD20 (D-10) from Santa Cruz Biotechnology, Inc. with additional staining of nuclei with Mayer's hematoxylin. Statistical analysis of the results was performed using a personal computer based on the Windows XP operating system using the statistical package "Statistica for Windows 6.0" (StatSoftInc.), Excel (Microsoft Office, USA).

Results. Intrafetal administration of staphylococcal toxoid led to partial lymphocytic infiltration of the stroma of the thyroid gland and the formation of intraorgan diffuse lymphoid tissue mostly from CD $3^{+}$and CD $4^{+}$lymphocytes (an increase in the number of T-lymphocytes over this period of 75.1 times) and its cooperation in the form lymphoid nodule on the 14th day of postnatal life, the cellular composition of which was immunohistochemically represented by $C D 3^{+} C D$ $4^{+}$and $\mathrm{CD} 3^{+} \mathrm{CD} 8^{+}$T-lymphocytes. This was accompanied by expansion and manifestations of stasis in the venules, activation of mast cells and macrophages. Such a morphological picture in the thyroid gland of antigen-premium animals was observed on the periphery of the gland. Thus, intense changes in the immunological compartment of the thyroid gland with the formation of diffuse lymphoid tissue in young rats after prenatal exposure to staphylococcal toxoid due to generalized prenatal antigen load in the body as a whole and are manifestations of reactivity in the formation of antigen-independent differentiation of T lymphocytes.

KEY WORDS: thyroid gland; staphylococcal toxoid; rats; immunological reactivity. 